\title{
ANALYSIS OF WASTE PRODUCTION MANAGEMENT AND ENVIRONMENTAL CONDITIONS ON COATING PROCESS PERFORMANCEBEFORE AND AFTER THE IMPLEMENTATION OF ENVIRONMENTAL MANAGEMENT SYSTEM (EMS)
}

\author{
Yetty Dwi Lestari (yettydl@yahoo.com) \\ Binar Prisilia \\ Faculty of Economic and business, Airlangga university
}

\begin{abstract}
The phenomenon of proactive environmental management began in the 1990's where manufacturing industries were aware the importance of corporate sustainability through sustainable environmental management. Various strategies can be done in a proactive environmental management. This study emphasized the development of conditions environmental performance companies in minimizing waste, especially in production process that contains a lot of waste. The company has trying to implement a standardized EMS, through its own sludge wastewater treatment as a raw material for making bricks, while for solid waste (zinc dross and zinc ash), had been sold to external parties from the beginning. There isn't recycling process, Galva furnace repair and improvement work on the system setting WWT or the WWTP. EMS implementation is strengthened through the acceptance of ISO 14000 in 2007. The condition of Company's environmental performance related to waste minimization in the galvanizing process before and after implementing EMS was measured using input indicators (material), the input of water and energy use, and output of products in the form of waste (solid or sludge). The result did not correspond quantitatively with the indicators used in ISO 14000. Based on the quantitative result, a company processing waste, did not change significantly.
\end{abstract}

Keywords : waste production management, coating process, performance, EMS

\section{Background}

21 'th Century is the new industrial revolution, stressing the company goal not only maximize the benefit, but also the achievement of environmental quality as a result of production activities has become a destination that is proportional to the increase in revenue, and made a part of corporate strategy. Environmental issues indicates that not only emphasizes the aspect of total quality management (TQM) through standardization of quality to achieve competitive advantage, but also on the environmental aspects of quality management (Quality of Environmental Management).

In the Corporate Social Responsibility (CSR) there are several components, one of which is corporate environmentalism or a shared understanding of the company regarding environmental concerns about the company. Corporate environmentalism is the most important component of CSR (Ronnenberg et al., 2010). This includes waste minimization and prevention, management (of the) demand, design for environment, product stewardship, and full-cost accounting (Ronnenberg et al., 2010).

Since the focus on the wider community, excessive pollution, minimization (use of) resources, hazardous waste, and other environmental issues, increased by more than one decade ago (Psomas, 2011), many companies choose to implement an environmental management system EMS) or a structured approach to show the line or bottom line of environment, as part of an effort to their environment (Ronnenberg et al., 2010). The bottom line assumption of EMS is whether it helps the company in achieving better environmental performance through standardized practices or activities, documentation, communication, and organizational learning (Ronnenberg et al., 2010). 


\section{Yetty Dwi Lestari}

The company has been trying to implement EMS, and to prove its success, the company seeks ISO certification standards, as evidenced, the Company obtain ISO 14001:2004 certification in 2007. Certainly hope for the companies that have successfully achieved ISO 14001 certification is how the waste does not pollute the environment and how waste can be minimized. Standard ISO 14001 is an environmental control management system associated with the minimization of waste. Thus, the ISO 14001 standard is used as a guideline in implementing the company's EMS or Environmental Management System.

Basically in ISO 14001 policy does not directly establish clear standards for effluent discharge. There is no terms quantity of waste in ISO 14001. However, the companies that has been certified must abide by local area environmental regulations. Therefore, the actual process of waste minimization in terms of quantity is also important to measure based on the reference to the Law on Environmental policies in Indonesia. until now the company do not measure the quantity of waste in the galvanizing process. This study want to measure how much change in the environmental performance of firms before and after implementation of EMS based on existing environmental indicators.

The Company has a machining department which is one process that requires the most attention to the handling of the environment in the process of galvanizing, the zinc coating on the pipe connection components. Because the galvanizing process is a process that requires a lot of input B3 (Hazardous and Toxic) and require much water. We need to know that the essence of its own green operations practices are also summarized green productivity theory, the manufacturing process should pay attention to minimize the use of raw materials, especially water and raw materials that contain input B3 (Pick, 2011). Through the minimization of water use and input B3, the amount of hazardous waste as well as the content of the liquid waste will be reduced

This study will try to examine a progress report of galvanizing process performance in pre and post conditions of EMS implementation. the calculated environmental performance indicators that are selected will show how large an increase in its environmental performance, especially the issue of waste minimization in the production process of galvanizing. The Company has a machining department which is one of its process requires the most attention to the handling of the environment in the galvanizing process, the zinc coating on pipe connection components. Because the galvanizing process is a process that requires a lot of input B3 (Hazardous and Toxic) and require much water. We need to know that the essence of its green operations practices are also summarized in the theory of green productivity, and the manufacturing process should pay attention to minimize the use of raw materials, especially water and raw materials that contain input B3 (Pick, 2011). Due to minimizing water use and input B3, the amount of hazardous waste as well as the content of the effluent will reduce. This study will try to examine a progress reportt on the process of galvanizing performance in pre and post conditions of EMS implementation. The calculated of selected environmental performance indicators will show how large an increase in its environmental performance, especially the issue of waste minimization in the production of the galvanizing process.

\section{LITERATURE REVIEW}

\section{Green Operations}

Green operations is an operation activities which aims to suppress or at least reduce the impact to the environment around organization neighborhood. These include corrective activities or improve the companies performance using system or working tools that are environmentally friendly. Most importantly, the company must pay attention to working conditions for environmental sustainability so well preserved. green practices operations also aware about activities that contribute to the enhancement or improvement of the quality of environmental performance in the company's operations (Nunes and Bennett, 2010). Green manufacturing operations included in the green operations (Rastogi, 2001). Green 
manufacturing is a method which are importance for manufacturing process in minimization of waste and pollution. Waste minimization and pollution can be done through giving more attention to product design and production processes (Foster, 2001). The main goal or purpose of green manufacturing is conserve natural resources for the survival of nature for future generations (Rastogi, 2001).

\section{Green Productivity}

Green productivity is a strategy to increase business productivity and environmental performance at the same time in the overall socioeconomic development. This method applying techniques, technologies and management systems to produce goods and services that suit to the environment or environmentally friendly. One important point is the use of water during the production process. How a company minimize water use as much as possible in production processes that most requires water (Pick, 2011). Green productivity is part of the productivity improvements that are environmentally friendly in order to answer the global issue of sustainable development (sustainable development). Green productivity is one of the concept that increased productivity and sustainable development (Pick, 2011). Green productivity has four general purpose (Pick, 2011): with Waste reduction

1. Material Management

2. Pollution Prevention

3. Product Enhancement

\section{Environmental Management System (EMS)}

Environmental management systems or environmental management system (EMS) contains a procedure that is organized and well-documented, and policies of a company that directly affect and control issues or environmental issues which may be owned by the company in the future (Ronnenberg et al., 2010). Environmental management system is the standard of compliance or statutes that are used for the achievement of ISO 14000. ISO 14000 uses the same basic approach as ISO 9000:2000 with documentation control, auditing management systems, operational control, control of supporting documents, management policy, auditing, training, statistical techniques, also corrective and preventive action.

EMS is an ongoing standardization or continuous. The most important thing and a challenge for companies (primarily been certified ISO standard 14000) is a way to maintain continuity. Basically Management Systems (EMS) is included in the green productivity and green operations. Moreover, some empirical studies indicate that the implementation of EMS can help companies reduce the use of input, maximizing the benefits from the use of raw materials, and the effect on the company's operational security (Sebhatu and Enquist, 2007).

\section{Proactive Environmental Management System}

According Cahyono (2009), proactive environmental management system is a comprehensive environmental management which consist four combination approaches:

1. Waste minimization and prevention

Effective environmental protection is needed preventive activity against useless activity. Pollution prevention is the use of materials or raw materials, production processes or practices that could reduce, minimize or eliminate the causes of pollution or pollution sources. Technologies related to pollution prevention in manufacturing include: replacement of raw materials, process modifications, material reuse, recycling material in further processing, and reuse of materials in different processes .

2. Demand side Management

An approach in prevention of pollution from industrial worl. This concept is focused on understanding the needs and preferences of consumers in using the 
product, and based on three fundamental principles: do not leave waste products, sold in accordance with the needs of consumers and make consumers more efficient in using the product.

3. Environment design /product stewardship

The purpose of the design environment here is a manufacturing company should be able to design products that can still be utilized again, especially if there is defective product. While the product stewardship practices undertaken to reduce the risk to the environment through the issues in the design, manufacture, distribution, use or sale of products. The Company shall be responsible to re-claim, re-cycling and remanufacturing of their products. By using life cycle analysis can be determined ways to reduce or eliminate corporate waste in all phases from raw materials, production, distribution and use by consumers. Alternative products that have less pollution and alternative raw materials, energy sources, processing methods that reduce waste become a necessity for companies.

4. Full-costing accounting

Full-costing accounting seeks to identify and quantify the performance of the environmental costs of a product, production process and a project to consider the four kinds of costs :

- Direct costs such as labor costs, cost of capital, and raw materials cost .

- Indirect costs such as costs of monitoring and reporting

- Uncertain cost such a repair costs

- Invisible costs, such as the cost of public relations and good will.

Environmental performance

Environmental performance is a measure of successfull environmental management by the company. At this time, the environmental performance is part of corporate strategy, in addition to other objectives company's performance. The second purpose of the company (databases must address satisfying environment and company performance) has a weight that is comparable in line with stakeholders demands. According Cahyono (2009), based on ISO 14001, environmental performance is defined: Measurement results or the environmental management system, related to an organization's control of its environmental policy, objectives and targets. Theyel (2000), assessing the environmental performance associated with a reduction in the effectiveness of activities that pose no added value. Determination of environmental performance can be done by assessing the level of the estimated percentage of waste reduction during the last three years. Further grouped into four categories:

1. Increase or no change $(0 \%)$

2. Little/slight reduction(1-10\%)

3. Simply / intermediate reduced (11-55\%)

4. Large / great reduction (51-100\%)

Corporate environmental performance is calculated with an average rate reduction of waste in the production process. Theyel (2000) emphasis on preventive measures, and then grouped into various levels to assess the level of success in environmental performance. Environmental performance indicators according to Rao (2002) in Cahyono (2009) again enhanced by Rao et al. (2006), judged from the following calculation,:

1. Raw Material eficiency

$$
\frac{\text { Input }}{\text { total product output }}
$$

2. Packaging to output ratio

$$
\text { jumlah pengepakan }
$$

total product output

3. Reusable packaging ratio 
[Type text]

4. Hazardous material ratio

input berbahaya

total input

1. Recyclable raw materials ratio

recyclable raw materials

total materials input

5. Energy cost/output

energy cost

total product output

6. Energy consumption

$$
\frac{\text { energy consumption }}{\text { total product output }}
$$

7. Renewable energy

renewable energy

total energy

8.

Water consumption

penggunaan air

total product output

9.

Total waste to output

total waste

total product output

10.

Recycling waste ratio

limbah dari bahan baku daur ulang

total limbah

11. Waste for disposal ratio

waste for disposal

total waste

12.

Hazardous waste ratio

limbah berbahaya

total limbah

13. Specific waste ratio of specific amount of waste (e.g. recyclable solid, sludge, etc. ) to total output product sludge

total output product

From the above formula will be generated environmental performance in terms of quantity. Quantitative performance indicators is a measure that is based on empirical data and numerical results that characterize the performance in the physical, financial, or other forms.

\section{RESEARCH METHODS}

RESEARCH APPROACH

This study used a qualitative approach with a descriptive exploratory case study method. With a focus on one object alone, but is analyzed in depth. Qualitative research methods are research methods used to examine the condition of natural objects in which the researcher as a key instrument (Sugiyono, 2009:14). The descriptive method will guide the research to explore and photograph the social situation broad and deep (Sugiyono, 2009:380).

\section{Research limitation}

Limitation of the study or the scope of this study are as follows: 
1. The study was conducted in machining production department that produces the most waste production, the galvanizing process

2. Historical data used is the data on environmental indicators in the galvanizing process to minimize waste during the condition before and after the implementation of EMS.

3. Tools used are indicators of environmental performance of Rao et al., Then the calculation of environmental performance indicators that minimize waste are classified into four categories refer to the classification level of environmental performance Theyel. Not refer to the ISO 14001 standard, because the standard does not explicitly provide indicators for EMS.

4. The study did not calculate the liquid waste, air pollution, the performance of WWT, because the company has not made measurements of the production process of waste water contaminated B3 input the input to the process of WWT and the measurement of the level of air emissions.

\section{Type and source data}

The data used in this study are the primary data, which is the main data in the form of explanation and research information provided by the company internally, either orally or in writing, as well as direct observation of the production activities carried out. Secondary Data, which is a complement to the data obtained from the literature study results obtained from written sources, literature and articles related to the formulation of research problems.

\section{Analysis techniques}

Data analysis consisted of testing, categorizing, or re-combining the evidence or data to designate a proportion of the initial study (Yin, 2004:133). Furthermore drawn a conclusion based on the results of combining the evidence collected from the problems to be answered, then the analytical techniques used in this study are as follows:

1. Identify the system that the company applied associated with the handling of waste production in the galvanizing process before and after the implementation of EMS. Identification is based on data from the internal corporate supporters who had gathered.

2. Calculating the environmental performance associated with the production of waste treatment processes before and after the implementation of environmental management systems based on environmental performance indicators owned by companies, especially in the galvanizing process.

3. Environmental performance indicators that can be measured, adjusted to the measured data in the Company:

A. Input indicators (Materials):

1. Amount of raw material per total product

2. Amount of hazardous material per total input

B. Input indicators(Energy):

1. Amunt of total energy use per product output

C. Input indicators(use of water) :

1. Amount of water use per total product output

D. Output indicators (waste) :

1. Amount of solid waste per total product output

2. Amount of sludge per total product output

After we calculate each indicator, the indicator for waste will be classified for reduction of waste each year into the specific categories based on Theyel theory. Analysis in terms of waste per total product produced in that year

4. Stages of the conclusions.

\section{Tahapan Penelitian}

Appropriate stages of research in solving thereserach problems is required to achieve good results.:

1. Conduct a preliminary survey to gain a clear picture of the issues

2. Doing problem formulation that occured in the company 
3. Determining the purpose of research based on the problem formulation.

4. Conduct field studies to collect data : data on flow chart galvanizing, types of waste generated during the process of galvanizing, the difference in waste minimization management before and after implementation of the EMS, data about the amount of product output produced, the number of inputs that are categorized as toxic materials and hazardous (B3), the amount of waste generated, including hazardous waste to the environment, and then calculated the ratio of environmental performance indicators. Other supporting data such as, water use, energy use during the production process. And then identify types of waste generated by galvanizing process.

5. Identification types of waste generated by galvanizing process.

6. Analysis of waste management condition on galvanizing process prior to implementation of EMS

7. Analysis of waste management condition on galvanizing process after implementation of EMS

8. Comparative analysis of environmental performance in the galvanizing process based on the results of calculations using environmental performance indicators on the condition before and after the implementation of EMS. Analyses were performed in terms of calculations per total waste product produced in that year.

9. Make conclusions based on the results of research

\section{RESULTS AND DISCUSSION}

Research will be focused on the process of galvanizing (zinc coating on the pipe connection), since there are quite a lot of malicious input is needed in this process. And environmental performance is primarily concerned with the minimization of waste in this area. Studies were performed to analyze the environmental performance of a progress report before and after the implementation of EMS in the galvanizing process.

Basically Galvanizing have to go through the following processes:

1. Water Rinsing : To eliminate the chemicals from degreasing.

2. Acid Pickling: To remove rust and scale of steel

3. Prefluxing: To avoid oxidation of the surface prior to immersion.

4. Oven : Drying the surface before it is put into a bath of zinc (Zn).

5. Galvanizing : Immersion into hot zinc liquid (Zn) .

6. Quenching : cooling as the final process on the surface of zinc (Zn).

Galvanizing line at each galvanizer company is the same. In accordance with this general principle. company usually use different terms on each of the stages in the galvanizing process . For instance, the oven means the same as the drying process. While the quenching process is another term for cooling process.

\section{IDENTIFICATION OF COATING PROCESS WASTE}

- Shot Blasting Process generate waste in form of dust, collected in dust collector and brought back to the foundry, because the dust will be collected in the dust collector eventually in which the processing performed in the foundry.

- The process of rinsing 1_generate water waste mixed with sand that may still be involved by casting, then the water waste is channeled to the WWT to be neutralized before it flowed into the river around the factory area.

- Pickling process generate water waste that has been contaminated with liquid $\mathrm{HCl}$ and $\mathrm{HF}$, then the waste is applied to WWT to neutralized the acid content before it flowed into the river around the plant area

- Waste from Rinsing process 2 form of contaminated water with fluids derived from the pickling, which is then channeled to the WWT to be neutralized before it flowed into the river around the factory area. 


\section{Yetty Dwi Lestari}

- Waste from Fluxing process, only in form of steam. Due to persistent warming, with temperatures around $80^{\circ} \sim 100^{\circ} \mathrm{C}$ the liquid turns into vapor flux. The processing time around $5 \sim 10$ minutes / batch.

- Setting process does not generated waste

- Dipping process generate solid waste in formof zinc dross and zinc ash. This process is the main process in galvanizing ( zinc coating on the pipe connection).

- Shake process does not generated waste

- Kentrok process aims to flatten the zinc attached to the casting. Flattening performed approximately 15 to 25 pounding. There is no waste from this process.

- Cooling process, before the company active implementing EMS, cooling water directly applied to the WWT to be neutralized before it flowed back into the river around the factory area.

- Inspection process actually sort between casting with repair tare. Casting which is not appropriate with the standard will be brought back to the foundry for the re-melting. So in fact there are no specific waste from this process 


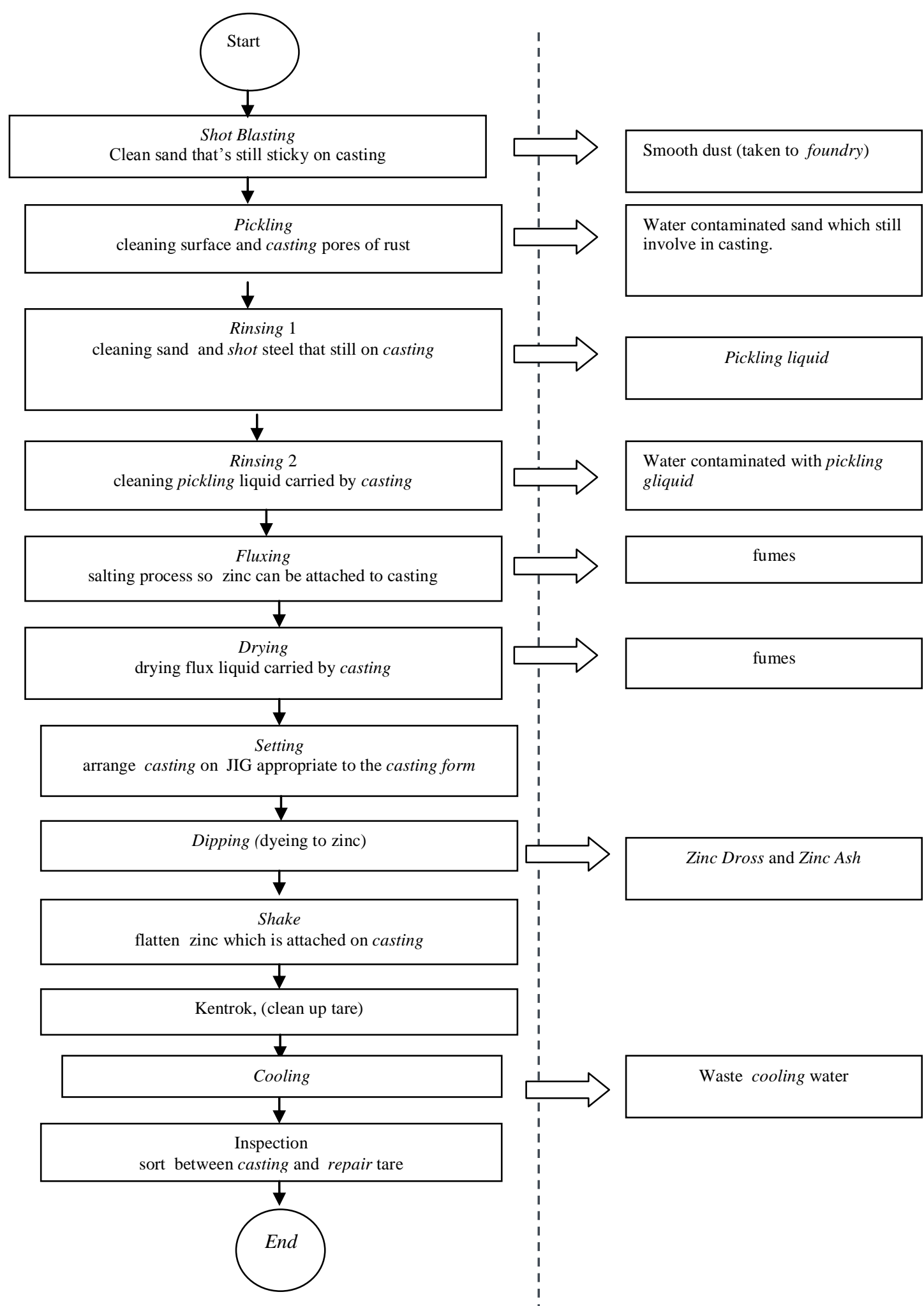

WASTE IDENTIFICATION ON GALVANIZING PROCESS ANALYSIS OF WASTE MANAGEMENT BEFORE IMPLEMENTING EMS ON GALVANIZING PROCESS

Before the company actively implements the EMS, waste that requires extra handling, come from pickling process. B3 Wastes containing input which is destructive because it's containe 


\section{Yetty Dwi Lestari}

liquid strong acids ( $\mathrm{HCl}$ and $\mathrm{HF}$ ). The next waste generated from the cooling process, before implementing EMS, cooling water from the cooling process directly channeled to WWT to be neutralized. There is no cooling water recycling process.

The next waste are waste from rinsing 1 and 2, both directly channeled to the WWT for neutralized the danger substances. While in the fluxing process, the waste generated is in form of fumes. Then for the dipping process, before implementation of the EMS, kettle or zinc to the liquid zinc bath place, made of steel with a maximum capacity of 8.9 tons with two burners on the two point locations. Last result of waste processing from the waste rinsing process 1 and 2, pickling wastes, cooling water waste that has been used for sludge. Before the company actively implements the EMS, the company is treating its own sludge waste as raw material for making bricks

\section{MANAGEMENT OF WASTE AFTER IMPLEMENTING EMS ON GALVANIZING PROCESS}

After company implemented an EMS, around the end of 2009, residual waste from pickling process is recycled for the next pickling process. Previously used pickling liquid accommodated in the pickling tank for 1 week and then adding $\mathrm{HCl}$ and $\mathrm{HF}$ liquid which will use in subsequent pickling process again. This system is expected to reduce the use of inputs in the form of $\mathrm{HCL}$ and $\mathrm{HF} \mathrm{B3}$, as well as reduce the workload of the WWT in neutralizing waste before it flowed back into theriver around the plant. In mid-2008, company did recycle through the used water cooling process to be reused on subsequent cooling process. with this innovation, the company expects water consumption can be reduced in cooling process. So in addition to minimizing waste, also affect the process of minimizing the use of good water as an inputs.

for the rinsing process 1 and 2, there is no differences in management of waste.So waste from rinsing process 1 and rinsing process 2 remains streamed to the WWT neutralized chemical ingredients. Similarly to waste from fluxing process. There wasn't difference in the management of waste between before and after implementation of the EMS. Fluxing waste remains in the vapor flux is no longer liquid.

Dipping process is the core of galvanizing process, generate solid waste in the form of zinc dross and zinc ash. After the company implemented an EMS, solid waste from the process of dipping is also minimized. Although waste isn't directly effect on the environment, by minimizing the amount of waste, it's equivalent to maximizing the use of zinc in each dipping processing. Around October-November of 2009, company began reforms the furnace Galva, zinc forms for zinc bath and capacity burner or heater location is also moved and reduced in number. Zinc bath which was made of steel with capacity around 8.9 tons, from late 2009 replaced with 2 pieces of zinc bath made of crucible (SIC) or silicon with each capacity around 1.7 tons. Replacement of the zinc bath is justified because the zinc bath is made of steel and reacts with the zinc ingot (the kind used as raw material zinc coating) is heated, and finally diluting the thickness of the zinc bath, this causes a lot of zinc fluid that seeps or drips, and ultimately will increase the amount of solid waste from the process. The company finally took the initiative to replace the zinc bath. Through the renewal of furnace Galva, the company expected, the solid waste generated from this process will be reduced, and it will be proved by the calculations of Rao et al. and further classified according to the Theyel theory before and after the implementation of EMS. From the beginning the management of solid waste performed by a third party.

The next waste is sludge, after the company actively implement EMS, around 2008, Company was working with third parties for processing sludge waste, Because after calculation. The costs more cheaper then managed their own. sludge is taken by third party every two years. The next difference regarding the management of waste production, is located on the system or the workings of WWT or the WWTP. Not all waste come into the WWT process. Wastes from fluxing process is a vapor, so it does not go into this process. Neither 
solid wastes from the dipping process, water waste recycling cooling after the cooling water used, as well as pickling waste after 2009.

WWT will be separated the production of waste water that has been neutralized with sludge waste. However, as previously described for the waste that has been neutralized in form of water can not be calculated, because so far the company does not measure the quantity of liquid waste. The Company was limited taking samples for examination in the laboratory to see if final waste is conform with the standards for effluent quality based on the Governors Decree No.45. 2002 about quality standards for industrial effluent or other business activities in East Java. Calculation of environmental performance indicators and performance analysis of the
environmental conditions before and after implementation EMS in galvanizing process

\begin{tabular}{|c|c|c|c|c|c|}
\hline 1 & Total Input & $\begin{array}{c}\text { Kg/Kg } \\
\text { product }\end{array}$ & 168.24 & 168.15 & 168.12 \\
\hline 2 & use of Input B3 & $\begin{array}{c}\mathrm{Kg} / \mathrm{Kg} \text { Total } \\
\text { Input }\end{array}$ & 0.0013 & 0.0009 & 0.0008 \\
\hline 3 & Use of water & $\begin{array}{c}\mathrm{m}^{3} / \mathrm{Ton} \\
\text { product }\end{array}$ & 168 & 168 & 167.9 \\
\hline 4 & Use of Energi & $\begin{array}{c}\mathrm{m}^{3} / \mathrm{Ton} \\
\text { product }\end{array}$ & 176 & 117.4 & 119.8 \\
\hline 5 & Sludge waste & $\begin{array}{c}\text { Ton/Ton } \\
\text { product }\end{array}$ & 0.068 & 0.044 & 0.36 \\
\hline 6 & $\begin{array}{c}\text { Solid waste } \\
\text { (zinc dross dan } \\
\text { zinc ash) }\end{array}$ & $\begin{array}{c}\text { Ton/Ton } \\
\text { product }\end{array}$ & 0.12 & 0.066 & 0.054 \\
\hline
\end{tabular}

Source : Data processed

The table above is calculation resume refers to the environmental performance indicators for the EMS during the years 2009, 2010, 2011. Because EMS is continuous improvement of its system, we can see from the table a progress report on corporate environmental performance related to the process of galvanizing waste minimization and its influence on the total input, input use B3 (hazardous and toxic materials), the use of water and the use of energy. The results from quantity calculation environmental performance is the actual result because its calculated by comparing the actual quantity of product produced in the galvanizing process.

Analysis of sludge can be started from the indicator, we can see in 2009, the sludge produced per ton for 0,068 tons or $6.8 \%$ output per product. Then in 2010 declined to 0,044 tons per products or $4.4 \%$, which means a small reduction in category. Whereas in 2011 , although the number dropped to 0,36 per Ton products or $3.6 \%$, but, still considered no change (significantly) from 2010, due to the decrease percentage is still below $1 \%$. Then if we see from solid waste, in 2009 produced the most solid waste than in 2010 and in 2011, this shows the Company's performance in minimizing solid waste proving good results. Although still relatively small reductions if we are referring to the theory of Theyel, because the percentage reduction is still in range $1-10 \%$.

Percentage of reduction in waste minimization is seen in the 2010 and 2011 , it; s effect on the use of total input galvanizing process, even if we look at the table, in fact in the last three years, in 2009, 2010 and 2011 there isn't different, apparently after we calculated by comparing the amount of output of products, we aren't seen a significant decrease from 


\section{Yetty Dwi Lestari}

year to year. In 2010, only declined $0,09 \mathrm{Kg} / \mathrm{Kg}$ of product in 2009 . Then in 2011 only decline $0.03 \mathrm{Kg} / \mathrm{Kg}$ of product in 2010 .

If seen from the indicators use for malicious input, there was also a decrease from year to year, though still the same as before, to use indicators B3 as input also has not shown a significant reduction in the numbers. But at least, the process of recycling the input B3 as the pickling process, reinforced by the results of this calculation. There was reduction in numbers in 2010 and 2011. Percentage reduction in the use of input B3 to the number of products produced did show a significant reduction, because the recycling process occurs only in the process of pickling alone. For fluxing process, there is no process of recycling, because waste is in form of steam. Neither the dipping process, the waste also has a zinc dross and zinc ash that can not be reprocessed for subsequent dipping process. Because zinc dross and zinc ash can not be recycled as raw material for the next dipping.

Furthermore, the effect of waste minimization is also on the amount of water use. One of them relates to the recycling process of cooling water. Although from the table above, it turns out when compared to the amount of output produced in that year, in 2009 and in 2011 showed the same numbers for indicators of water use is equal to $168 \mathrm{~m} 3$ per ton of products. In 2011 there was a slight decline to $167.9 \mathrm{~m} 3$ per ton of products. But remember back to the previous explanation, in 2010, actually increase the number of products produced from 789 tons in 2009 to 1030.5 tons in 2010. Which means that although the figures showed the same, in fact there is an increased efficiency of water use in 2010 by the galvanizing process to the company. So the innovation that has carried by company on cooling water recycling process in 2008 , a completely new show results in 2010 , there was an increase in output of products produced, but rather there wasn't increase in water use. Figure the amount of water use in 2009 and 2010 showed the same rate of $168 \mathrm{~m} 3$ per ton of products, this means company performance began show improvement in minimizing water use during the galvanizing process. So then, hopefully it can continue to be maintained. By regularly disseminating the importance of environmental awareness training to employees through the holding of K3 (health and safety).

In terms the use of energy appears there was a significant reduction from 2009 to 2011. Whereas in 2010 and in 2011 an increasing number of products produced, and the use of energy for each ton of products also increases. Based on the above calculation, it can be proved that waste minimization processes of the company in the galvanizing process, also has an effect on energy use. One of them could be linked to reforms in Galva furnace which reduces the capacity of zinc bath (dipping process), because the burner (heater) minus one, reducing energy usage for the burner.

\section{Conclucions}

Some conclusions that can be stated:

1. In 2006, before the Company is actively implementing a standardized EMS, the Company still treating its own sludge waste as a raw material for making bricks, while for solid waste (zinc dross and zinc ash), from the beginning had been sold to external parties. And still there is no recycling process, Galva furnace repair and improvement work on the system setting WWT or the WWTP.

2. The company's environmental performance conditions related to waste minimization in the galvanizing process before implementing an EMS company as measured by input indicators (material), the input of water and energy use, output of products in form of solid or sludge which in 2006 was to waste sludge per ton of products galvanized pipe joints for 0082 Ton per ton product $=8.2 \%$ per ton of products. While solid waste (zinc dross and zinc ash) per ton of galvanized pipe fittings products 0.88 tons per ton product $=8.8 \%$ per ton of products.

3. Management of waste minimization in the process of galvanizing production (solid waste and sludge) is performed after the company implementing an EMS is as follows: 

a. Reuse cooling water for the next cooling process
b. Reuse HCL and HF liquid, from pickling process residual, for the next pickling process. Old fluid coupled with adding a new liquid $\mathrm{HCl}$ and $\mathrm{HF}$.
c. Improvement to furnace galva through changing kettle or zinc bath that made from steel with kettle or zinc bath that made from crucible (SIC) or silicon, reducing maximum capacity of zinc bath, changing burner lay out .
d. Improvement on pump setting of WWT, including the addition of aeration system.

4. The company's environmental performance conditions related to waste minimization in the galvanizing process after implementing the EMS as measured by input indicators (material), the input of water and energy use, output and output of products in form of waste (solid or sludge) is if the amount of waste compared to the output of pipe joints are produced, in 2007 (the achievement of ISO 14001 certification of the EMS), for sludge per Ton $=0,073$ products $=7.3 \%$ per ton of products. It's means decrease $0.9 \%$ from 2006 (the category of no change (mean)). While solid waste per Ton $=0,078$ products $7.8 \%$ per Ton of products. It's means decrease $1 \%$ from the year 2006 (category slightly reduced). In 2008 for sludge per Ton $=0,056$ products $=5.6 \%$ per ton of products. It's means decrease $1.7 \%$ from 2007 (category slightly reduced). While solid waste per Ton $=0,071$ products $=7.1 \%$ per ton of products. It's means decrease $0.7 \%$ from 2007 (no change category). Whereas in 2009 for sludge per Ton $=0,068$ products $=6.8 \%$ per ton of products.It's means an increase $1.2 \%$ from r 2008 (category slight increase). While solid waste per Ton 0.12 or $12 \%$ per ton of products. It's means an increase $4.9 \%$ from 2008 (category slight increase). In 2010 for sludge per Ton $=0,044$ products $=4.4 \%$ per ton of products. It's means a decrease $2.4 \%$ from 2009 (category slightly reduced). While solid waste per Ton $=0,066$ products $=6.6 \%$ per ton of products. It's means a decrease $5.4 \%$ from 2009 (category slightly reduced). And in 2011 for sludge per Ton $=0,036$ products $=$ $3.6 \%$ per ton of products. That means a decrease .8\% from 2010 (category no change). While solid waste per Ton 0,054 or $5.4 \%$ per ton of products. It's means a decrease $1.2 \%$ from 2010 (category slightly reduced).

\section{References}

A Guide to Corporate Environmental Indicators. Federal Environment Ministry Bonn and Federal Environmental Agency Berlin. 1997.

Arifiani, Nur. F., Hadiwidodo, M. Tanpa Tahun. Evaluasi Desain Instalasi Pengolahan Air PDAM Ibu Kota Kecamatan Prambanan Kabupaten Klaten. Semarang: Program Studi Teknik Lingkungan Undip.

Bright, Mark A. et al. 2007. TMS (The Minerals, Metals \& Material Society) Online Journals : The Advantages of Recycling Metallic Zinc From The Processing Wastes of Industrial Molten Zinc Applications, (Online), (http://www.pyrotek.info/documents/techpapers/2007_adv_recycling_zin c_from_waste-tp-bright_deem_fryatt.pdf diakses tanggal 10 April 2012 Pada Pukul 21.45)

Cahyono, B. 2009. Analisis Berbagai Dimensi Lingkungan Pada Industri Manufaktur Di Jawa Tengah. Jurnal Studi Lingkungan, Vol. 1(1), 11-25.

Foster, S. Thomas. 2001. Managing Quality: An Integrative Approach. Upper Saddle River: Prentice Hall.

Fryatt, John. 2010. Sustainability in Galvanizing from In-house Applied Waste Management of General Hot Dip Galvanizing Ashes and Skimming and Continuous Galvanizing Line Top Drosses. Colombia: LATINGALVA Assembly.

Gonzales, et al. 2008. Environmental management system certification and its influence on corporate practices: Evidence from the automotive industry. International Journal of Operation \& Management. Vol.28(11), 1021-1041.

Nugraha, Happy. 2011 . Pengukuran Produktivitas dan Waste Reduction Dengan Pendekatan Green Productivity (Studi Kasus : UD Sumber Jaya). Surabaya: Tugas Akhir Teknik Industri ITS. 
Nunes, B., Bennett, D. 2010. Green Operations initiatives in the automotive industry : An environmental reports analysis and benchmarking study. Benchmarking: An International Journal, Vol.17(3), 396-420.

Nuraini F, Eiffeliena. 2010. Pengaruh Environmental Performance dan Environmental Disclosure Terhadap Economic Performance (Studi pada Perusahaan yang Terdaftar di Bursa Efek Indonesia). Semarang: Universitas Diponegoro.

Psomas, et al. 2011. Motives, difficulties and benefits in implementing the ISO 14001 Environmental Management System. Management of Environmental Quality: An International Journal, Vol.22(4), 502-521.

Purwanto, Andie Tri. 2007. Pengukuran Kinerja Lingkungan, hlm. 1-25.

Rao, et al. 2006. Environmental indicators for small and medium enterprises in the Philippines: An empirical research. Journal of Cleaner Production 14, 505-515.

Rastogi, Swati. 2001. Green Manufacturing, (Online), (http://www.freequality.org/GreenManufacturing, diakses 10 April 2012 Pada Pukul 20.45)

Ronnenberg, et al. 2010. The important role of change management in environmental management system implementation. International Journal of Operations \& Production Management, Vol.31 (6), 631-647.

Sugiyono. 2009. Metode Penelitian Bisnis. Bandung: CV ALFABETA

Theyel, Gregory. 2000. Management Practice for Environmental Innovation and Performance. International Journal of Operation \& Production Management. Vol.20(2), 249-266.

United States Environmental Protection Agency. 2009. EMS action plan, (Online), (http//www.epa.gov/EMS/position/intro.htm, diakses 12 Desember 2011 Pada Pukul 11.30 
[Type text] 